\title{
Araştırma
}

Mersin Univ Saglık Bilim Derg 2019;12(1):113-125

doi:10.26559/mersinsbd.50276

\section{Tıp öğrencilerinde uzmanlaşma eğilimi, uzmanlık alan seçimi ve etkileyen faktörler}

\author{
Bilgehan Açıkgöz ${ }^{1}$, Ayşegül Ekemen², Işıl Zorlu², Nehir Aslan Yüksel², \\ Ferruh Niyazi Ayoğlu ${ }^{3}$
}

${ }^{1}$ Dr. Öğr. Ü., Zonguldak Bülent Ecevit Üniversitesi Tıp Fakültesi Halk Sağlığı AD

${ }^{2}$ Ar. Gör. Dr., Zonguldak Bülent Ecevit Üniversitesi Tıp Fakültesi Halk Sağlığı AD

${ }^{3}$ Prof. Dr., Zonguldak Bülent Ecevit Üniversitesi Tıp Fakültesi Halk Sağlığı AD

Öz

Amaç: Uzmanlaşma eğilimi ve uzmanlık alanı seçimi tıp öğrencileri ve hekimlerin kariyer planlamalarının iki temel unsurudur ve kariyer planlamasına yönelik tercihler tıp eğitimi sırasında şekillenmektedir. Bu çalışma tıp fakültesi öğrencilerinin kariyer planlamaları ve etkileyen faktörleri değerlendirmek amacıyla planlanmıştır. Yöntem: Kesitsel tipteki çalışma 798 tıp öğrencisinin katılımı ile gerçekleştirilmiştir. Bulgular: Öğrencilerin \%85,7'sinin kariyer planı uzmanlaşmaktır. Uzmanlaşma isteği kadınlarda, preklinik dönemde, aile ve akrabalarında hekim ve/veya uzman hekim bulunanlarda diğerlerinden daha yüksektir. En çok tercih edilen uzmanlık alanları Cocuk Sağlığı ve Hastalıkları, Kadın Hastalıkları ve Doğum ile Ruh Sağlığı ve Hastalıklarıdır. Uzmanlık yönünde kariyer planlaması yapan öğrencilerde temel gerekçeler "mesleki tatmin sağlayacak spesifik bir alanda çalışma isteği", "statü ve kariyer beklentisi" ile "maddi kaygllar" iken, pratisyen hekimlik yönünde kariyer planlaması yapan öğrencilerde temel gerekçeler "Tıpta Uzmanlık Sınavının varlığı", "Asistanlık sürecinin zorluğu" ve "Ülkemizdeki sağlık politikalarıdır". Sonuç: Hekimlerin uzmanlaşma eğilimlerinin tespit edilmesi ve tartışılması sağlık insangücü planlamasında önemli rol oynayacaktır.

Anahtar kelimeler: Tıp fakültesi, öğrenci, uzmanlık

Yazının geliş tarihi:25.12.2018 Yazının kabul tarihi:16.03.2019

Sorumlu Yazar: Dr. Öğr. Üyesi Bilgehan Açıkgöz, Zonguldak Bülent Ecevit Üniversitesi Tıp Fakültesi Halk Sağlığı Anabilim Dalı, ZBEÜ Tıp Fakültesi Halk Sağlı̆̆ AD 67600 Kozlu/Zonguldak, Tlf: 03722613240, e-posta: bilgehanacikgoz@yahoo.com, 


\title{
Specialization tendency, specialty choise and affective factors in medical students
}

\begin{abstract}
Aim: Specialization tendency and choice of specialty are two essential issues in career planning of medical students and physicians, and career-planning preferences are shaped during medical education. Methods: This cross-sectional study was planned to evaluate the career-planning and affective factors among medical students and performed with the participation of 798 medical students. Results: First of all, $85,7 \%$ of the students had specialization tendency in their career plans. Among the female students; specialty determining was observed higher in female students, preclinic students and who have physicians and/or specialist in their family and relations than other groups of students. The most preferred specialties are pediatrics, gynecology and obstetrics and psychiatry. While the main causes for students who are planning career in a specialty are "to desire to working in a specific area provide professional satisfaction", "status and career expectancy" and "concern for income", the main causes for students who are planning career in general practioner are "existence of Medical Specialty Examination", "difficulty of residency period" and "national health politics". Conclusion: Identifying and discussing the specialization tendency of physicians will play an important role in health workforce planning.
\end{abstract}

Keywords: Medical faculty, student, specialization

\section{Giriş}

Hekimlerin temel karar verici ve uygulayıcı olarak yer aldıkları tıp, genel anlamda, sağlığın korunması ve geliştirilmesi, sağlık sorunlarının tanı ve tedavisi ile uğraşan bir bilim ve sanat dalı olarak tanımlanabilir. Hekimler, profesyonel meslek yaşamına başlamadan önce, toplumların sosyal, kültürel ve ekonomik özellikleri, sağlık göstergeleri ve gereksinimlerine göre farklılıklar içerebilen, bununla birlikte temel içeriği küresel ölçekte belirlenmiş ve yaşam boyu devam edecek bir etkinlik ve eylemlilik olarak tanımlanan mezuniyet öncesi tıp eğitimi (MÖTE) programını tamamlamak zorunluluğundadırlar. MÖTE'ni tamamlayarak "Tıp Doktoru" unvanı alan hekimler, profesyonel meslek yaşamlarına, farklı ülkelerde farklı isimlendirmeler kullanılabilen bu unvanla devam edebilecekleri gibi, yüksek lisans, doktora veya uzmanlık eğitimi gibi mezuniyet sonrası eğitim programlarına (MSEP) katılarak belirli bir alanda uzmanlaşmaya da yönelebilirler. Söz konusu programlara katılım koşulları ve tanımlanmış yeterlilikler farklı ülkelerde farklı içeriklerle düzenlenmiş durumdadır. Ülkemizde hekimlerin söz konusu MSEP içerisinde yoğunlukla tercih ettikleri program tıpta uzmanlık eğitimi programları (TUEP) olarak belirginleşmektedir. Hekimler tarafından uzmanlaşma ve uzmanlık alanı seçimi konusunda verilen kararın, hekimin kişisel tercih ve hedeflerinin yanısıra, uzmanlaşmaya yönelik ulusal politika, planlama ve stratejiler, pratisyen ve uzman hekimlere tanınan haklar, farklılaşan çalışma koşulları, ücretlendirme politikaları, toplum ve meslek üyeleri tarafından bu unvanlara atfedilen anlamlar ve statüler gibi çok sayıda değişkenin doğrudan ya da dolaylı rol oynadığı bir sürecin birleşik sonucu olarak ortaya çıktığı düşünülebilir.

Sağlık Bakanlığı verilerine göre, 2017 yılında ülke genelinde 80951'i $(\% 54,0)$ uzman, 24397'si (\%16,3) asistan/araştırma görevlisi, 44649'u $(\% 29,7)$ pratisyen hekim olmak üzere 149997 hekim bulunmaktadır. ${ }^{1}$ Başka bir ifade ile, 2017yılında ülkemizdeki hekimlerin \%70,3'ü uzman veya uzmanlaşma sürecindedir. $\mathrm{Bu}$ veriler uzmanlaşmanın hekimler içinde de yoğun bir biçimde tercih edildiğini destekleyecek niteliktedir. Uzmanlaşma ve uzmanlık alanı seçimine yönelik karar sürecinin başlangıç noktasını tanımlamak oldukça zordur. Bununla birlikte, 
öğrencinin mesleğine yönelik bilgi ve becerileri edinmeye başladığı, sağlık hizmetleri sunumuna yönelik bilgiler ve deneyimler kazandığı, farklı çalışma ortamlarını deneyimleyerek gözlemlediği Tıp Fakültesi, karar sürecinin başlaması ve şekillenmesinde önemli ve belirgin etki oluşturabilir. Tıp öğrencilerinin uzmanlaşma ve uzmanlık alanı tercihlerini etkileyebilecek dinamiklerin tanımlanması, sağlık insangücü yetiştirilmesine yönelik ulusal politika ve planlamaların yönetiminde önemli bir girdi sağlayacak niteliktedir. Bu çalışmanın temel amacı Tıp Fakültesi öğrencilerinin uzmanlaşma ve uzmanlık alanı tercihleri ile bu tercihleri etkileyen etmenlerin değerlendirilmesidir.

\section{Yöntem}

Araştırma bölgesi ve popülasyonu: Zonguldak Bülent Ecevit Üniversitesi 1992 yılında Zonguldak Karaelmas Üniversitesi adıyla kurulmuş olup Tıp Fakültesi Mezuniyet Öncesi Eğitim Programı 2000-2001 eğitimöğretim döneminde başlamıştır. Entegre sistem ile eğitim yapmakta olan fakültede çalışmanın gerçekleştirildiği 2017 yılında 139 öğretim üyesi, 184 araștırma görevlisi görev yapmaktadır ve 876 kayıtlı öğrencisi bulunmaktadır. MÖTE Programı 01.01.2018 tarihinden itibaren altı yll süreyle akredite edilmiştir. Araştırmada örnekleme yöntemi kullanılmadan öğrencilerin tümüne ulaşılması planlanmış ve çalışma araştırmaya katılmayı kabul eden $798 \quad(\% 91,1)$ katılımcı ile tamamlanmıştır. planlanmıştır.

Araștırma tipi: Araştırma kesitsel tipte

Araştırmanın veri kaynaklart: Çalışmada kullanılan veriler, araștırmacılar tarafından geliștirilen, katılımcıların sosyodemografik özellikleri, uzmanlaşma ve uzmanlık alanı tercihlerini belirlemeye yönelik sorular içeren anket formu kullanılarak toplanmıștır. Açık uçlu soru içermeyen anket formunda katılımcıların konuya yönelik mevcut tercihlerini belirleyen sorular yanında, geçmişe dönük olarak tıp eğitimi süresince uzmanlık tercihlerinin değişip değişmediğini sorgulayan sorular da bulunmaktadır.

Araştırmanın uygulanması ve uygulayanlar: Araştırma 15 Kasım-15 Aralık 2017 tarihleri arasında yapılmış, veri toplamak amacıyla kullanılan anket formları araştırmacılar tarafından uygulanmıştır.

Ístatistiksel değerlendirme: Veriler bilgisayar ortamına aktarlarak değerlendirilmiş, tanımlayıcı veriler sayı, yüzde ve "aritmetik ortalama \pm standart sapma" şeklinde gösterilmiş, gruplar arası karşılaştırmalarda Ki-kare Testi ve Yates Düzeltmeli Ki-kare Testi kullanılmış, analiz sonuçları \%95 güven aralığında değerlendirilmiştir.

Etik kurul onayı: Araştırma için gerekli etik kurul onayı, Bülent Ecevit Üniversitesi Klinik Araştırmalar Etik Kurulu'nun $22 / 11 / 2017$ tarih ve $2017 / 19$ sayılı onayı ile alınmıştır.

\section{Bulgular}

Araștırmaya katılan ve yaşları 17-33 arasında değișen 798 öğrencinin \%57,1'i kadın, \%42,9'u erkektir, ortalama yaş $21,2 \pm 2,2$ 'dir. Öğrencilerin \%38,1'i $(n=304)$ sınıf ve/veya staj tekrarı yapmıștır. Sınıf ve/veya staj tekrarı yapan öğrencilerin \%59,0'1 (n=180) 1. sinifta, \%31,0'ı (n=94) 2. sinıfta, \%5,0'ı $(n=16) 3$. sinıfta, \%10,0'ı $(n=30)$ dahili bilimler, \%3,0'1 (n=8) cerrahi bilimler stajlarında tekrar yapmıştır. Katılımcıların $\% 35,0$ 'ının aile ya da akrabalarında hekim olduğu ve bu hekimlerin \%69,5'inin uzman olduğu tespit edilmiștir.

Öğrencilerin \%85,7'si (n=684) tıp fakültesini bitirdikten sonra uzman olmak istediğini, \%14,3'ü $(n=114)$ ise uzmanlık eğitimi almak istemediğini belirtirken, uzmanlık eğitimi almak istemediğini belirten 114 öğrenciden 26'sı $(\% 22,8)$, fakülteye başlarken uzman olmayı istediklerini ancak eğitim sürecinde bu kararlarının değiștiğini belirtmiştir. Tıp öğrencilerinin uzmanlaşma isteği çeşitli değişkenler yönünden 
incelendiğinde (Tablo-1) öğrencinin sinıf ve/veya staj tekrarı yapmış olması yönünden gruplar arasında anlamlı farklılık gözlenmezken $(\mathrm{p}=0,766)$, ögrencinin cinsiyeti $(p<0,001)$, okuduğu sinif $(p=0,045)$, aile ve akrabalarında hekim bulunması $(\mathrm{p}=0,003)$ ile aile ve akrabalarında uzman hekim bulunması $(\mathrm{p}=0,013)$ yönünden gruplar arasında istatistiksel olarak anlamlı farklılık olduğu saptanmıştır. Uzmanlaşma isteği kadınlarda, preklinik dönemde, aile ve akrabalarında hekim bulunanlarda ve aile ve akrabalarında uzman hekim bulunanlarda diğerlerinden daha yüksektir.

Tablo 1. Tıp öğrencilerinin uzmanlaşma isteği ile çeşitli değişkenlerin karşılaştırılması

\begin{tabular}{|c|c|c|c|c|c|c|}
\hline \multirow[t]{3}{*}{ Değişken: } & & \multicolumn{4}{|c|}{ Uzmanlaşma İsteği } & \multirow[b]{3}{*}{$\mathrm{p}$} \\
\hline & & \multicolumn{2}{|c|}{ Var } & \multicolumn{2}{|c|}{ Yok } & \\
\hline & & $\mathrm{n}$ & $\%$ & $\mathrm{n}$ & $\%$ & \\
\hline \multirow[t]{2}{*}{ Cinsiyet } & Kadın & 408 & 89,5 & 48 & 10,5 & \multirow{2}{*}{$<0,001$} \\
\hline & Erkek & 276 & 80,7 & 66 & 19,3 & \\
\hline \multirow[t]{3}{*}{ Sinifa } & Preklinik & 433 & 87,1 & 64 & 12,9 & \multirow{3}{*}{0,045} \\
\hline & Klinik & 184 & 86,0 & 30 & 14,0 & \\
\hline & İntörn & 67 & 77,0 & 20 & 23,0 & \\
\hline \multirow[t]{2}{*}{ Sinıf/staj tekrarı } & Var & 262 & 86,1 & 42 & 13,9 & \multirow{2}{*}{0,766} \\
\hline & Yok & 422 & 85,4 & 72 & 14,6 & \\
\hline \multirow[t]{2}{*}{ Aile ve akrabalarda hekim } & Var & 253 & 90,6 & 26 & 9,4 & \multirow{2}{*}{0,003} \\
\hline & Yok & 431 & 83,0 & 88 & 17,0 & \\
\hline \multirow{2}{*}{$\begin{array}{l}\text { Aile ve akrabalarda } \\
\text { uzman hekim }\end{array}$} & Var & 182 & 93,8 & 12 & 6,2 & \multirow{2}{*}{0,013} \\
\hline & Yok & 71 & 83,5 & 14 & 16,5 & \\
\hline
\end{tabular}

aIllk üç sınıf preklinik, 4 ve 5. sınıflar klinik, 6. sınıf intörn olarak gruplandırılmıştır

Öğrencilerin uzmanlaşma isteğini belirleyen nedenler incelendiğinde (Tablo-2) ilk sırada \%74,8 sıklıkla "Mesleki tatmin sağlayacak spesifik bir alanda çalışma isteği" bulunmakta, bunu \%64,3 ile "Statü ve kariyer beklentisi", \%38,1 sıklıkla "maddi kayglar" izlemektedir. Mezuniyet öncesi tıp eğitimini tamamladıktan sonra uzmanlık eğitimi almak istemeyenlerin nedenleri incelendiğinde ilk sirada \%70,9 ile "Tıpta uzmanlık sinavinın varlığı" bulunmakta, bunu \%63,6 siklıkla "Asistanlık sürecinin zorluğu" ve \%33,6 sıklıkla "Ülkemizdeki sağlı politikaları" izlemektedir.
Uzmanlaşmak isteyen öğrencilerin tıp eğitimine başlarken uzmanlık alanlarına yönelik tercihleri \%1,5 temel bilimler, \%38,6 dahili bilimler, \%40,2 cerrahi bilimler, \%19,7 kararsız şeklindeyken, tıp eğitimi süresince bu dağılım \%2 temel bilimler, \%47,4 dahili bilimler, \%43,0 cerrahi bilimler, \%7,6 kararsız şeklinde değişmiştir. Eğitim süresince uzmanlık tercihi değișen öğrenci oranı \%46,5'dir ve en çok değişim \%26,6 ile 4 . sinıf öğrencilerinde ve \%22,2 ile 2. sinıf öğrencilerinde yaşanmıştır. Uzmanlık alanı tercihi değișen öğrenciler bunun en sik nedenlerini "Derslerden ve stajlardan etkilenme" ve "Eğitim süresince ilgi alanının değişmesi" olarak ifade etmişlerdir. 
Kariyer planlamasında uzmanlaşmak istediğini belirten 684 katılımcıdan 632'si uzmanlık alanına yönelik tercihini belirlemişken, uzmanlaşmak isteyen 52 katılımcı ise uzmanlık alanına yönelik herhangi bir tercih belirtmemiştir. Uzmanlaşmak istediği alanı belirten öğrencilerin temel bilimler, dahili bilimler ve cerrahi bilimler alanlarında uzmanlaşma istekleri çeșitli değişkenler yönünden değerlendirildiğinde sadece cinsiyet yönünden anlamlı farklılı $(p=0,007)$ gözlenirken, diğer değişkenler yönünden anlamlı farklılık saptanmamıştır (Tablo-3). Temel bilimler, dahili bilimler ve cerrahi bilimler alanlarında uzmanlaşma isteği sirasiyla kadınlarda \%1,3, \%55,8 ve $\% 42,9$, erkeklerde $\% 3,5, \% 44,5$ ve $\% 52$ 'dir.

Tablo 2. Tıp fakültesi öğrencilerinin mezuniyet öncesi tıp eğitimi sonrasında uzmanlaşmayı isteme ve istememe nedenleria

\begin{tabular}{lcc}
\hline Neden: & $\mathrm{n}$ & $\%$ \\
\hline Uzmanlaşmayı isteyenler (n=684) & 511 & 74,8 \\
Mesleki tatmin sağlayacak spesifik bir alanda çalışma isteği & 439 & 64,3 \\
Statü ve kariyer beklentisi & 260 & 38,1 \\
Maddi kaygılar & 226 & 33,1 \\
Pratisyen hekimliğin değersizlik algısı & 200 & 29,3 \\
Uzmanlık eğitiminin başarı göstergesi olarak algılanması & 154 & 22,5 \\
Pratisyen hekimlik ile ilgili sağlık politikaları & 143 & 20,9 \\
Aile ve /veya toplum baskısı & 104 & 15,2 \\
Özel sektörde çalışma isteği & 14 & 2,0 \\
Diğer nedenlerb & & \\
& & \\
Uzmanlaşmayı istemeyenler(n=114) & 78 & 70,9 \\
Tıpta uzmanlık sınavının varlığı & 70 & 63,6 \\
Asistanlık sürecinin zorluğu & 37 & 33,6 \\
Ülkemizdeki sağlı politikaları & 36 & 32,7 \\
Uzmanlıkta çalışma şartlarının daha ağır olması & 34 & 30,9 \\
Uzmanlıkta hasta sorumluluğunun daha fazla olması & 22 & 20,0 \\
Uzmanlık sonrası zorunlu hizmet varlığı & 22 & 20,0 \\
Uzmanlık eğitimi ve sonrası ile ilgili sıkıntıları yaşamama isteği & 17 & 15,5 \\
Uzmanlığın maddi açıdan tatmin edici olmaması & 2 & 1,8 \\
Diğer nedenlerc & &
\end{tabular}

aKatılımcılar birden fazla seçeneği işaretleyebilmektedir.

'Katılımcılar tarafından "tercih edilen branşa özel ilgi duyma”, "yurtdışında çalışma isteği", "bilimsel çalışma yapma isteği", "daha rahat bir hayat yaşama isteği", "ülkeye hizmet etme isteği" ve "farklı ülkelerde gönüllü çalışma isteği” olarak ifade edilmiştir.

cKatılımcılar tarafından "tıp okumanın yeterince zor olması" ve "asistanlığın 4 yıl olması" olarak ifade edilmiştir. 
Tablo 3. Tıp öğrencilerinin temel bilimler, dahili bilimler ve cerrahi bilimler alanlarında uzmanlaşma isteği ile çeşitli değişkenlerin karşılaştırılması

\begin{tabular}{|c|c|c|c|c|c|c|c|c|}
\hline \multirow[b]{2}{*}{ Değişkenler } & & \multicolumn{2}{|c|}{ Temel Bilimler } & \multicolumn{2}{|c|}{ Dahili Bilimler } & \multicolumn{2}{|c|}{ Cerrahi Bilimler } & \multirow[b]{2}{*}{$\mathrm{p}$} \\
\hline & & $\mathrm{n}$ & $\%$ & $\mathrm{n}$ & $\%$ & $\mathrm{n}$ & $\%$ & \\
\hline \multirow[t]{2}{*}{ Cinsiyet } & Kadın & 5 & 1,3 & 211 & 55,8 & 162 & 42,9 & \multirow{2}{*}{0,007} \\
\hline & Erkek & 9 & 3,5 & 113 & 44,5 & 132 & 52,0 & \\
\hline \multirow[t]{3}{*}{ Sinıfa } & Preklinik & 10 & 2,5 & 186 & 47,3 & 197 & 50,1 & \multirow{3}{*}{0,119} \\
\hline & Klinik & 2 & 1,2 & 99 & 57,6 & 71 & 41,2 & \\
\hline & İntörn & 2 & 3,0 & 39 & 58,2 & 26 & 38,8 & \\
\hline \multirow[t]{2}{*}{ Sinıf/staj tekrarı } & Var & 8 & 3,3 & 112 & 46,7 & 120 & 50,0 & \multirow{2}{*}{0,091} \\
\hline & Yok & 6 & 1,5 & 212 & 54,1 & 174 & 44,4 & \\
\hline \multirow{2}{*}{$\begin{array}{l}\text { Aile ve akrabalarda } \\
\text { hekim }\end{array}$} & Var & 2 & 0,8 & 130 & 54,4 & 107 & 44,8 & \multirow{2}{*}{0,118} \\
\hline & Yok & 12 & 3,1 & 194 & 49,4 & 187 & 47,5 & \\
\hline \multirow{2}{*}{$\begin{array}{l}\text { Aile ve akrabalarda } \\
\text { uzman hekim }\end{array}$} & Var & 1 & 0,6 & 93 & 54,1 & 78 & 45,3 & \multirow{2}{*}{0,765} \\
\hline & Yok & 1 & 1.5 & 37 & 55,2 & 29 & 43,3 & \\
\hline
\end{tabular}

aİlk üç sınıf preklinik, 4 ve 5. sınıflar klinik, 6. sınıf intörn olarak gruplandırılmıștır

Tıp eğitimini tamamladıktan sonra uzmanlaşmak isteyen öğrencilerin \%7,6'sı uzmanlık alanına karar vermemiş iken, $\% 47,4$ 'ü dahili bilimler, \%43,0'ı cerrahi bilimler ve \%2,0'ı temel bilimler alanlarında uzmanlaşmak istemektedir. Uzmanlık eğitimi bulunan 36 alan içerisinde öğrenciler tarafından en çok uzmanlaşılmak istenen üç alan sırasıyla Cocuk Sağlığı ve Hastalıkları $(\% 9,9)$, Kadın Hastalıkları ve Doğum $(\% 6,6)$ ile Ruh Sağlığı ve Hastalıkları $(\% 6,5)$ olarak belirtilmektedir ve uzmanlaşma isteğinde bulunan öğrencilerin yaklaşık 2/3'ünün $(n=434, \% 63,5)$ tercihleri 10 uzmanlık alanında yoğunlaşmaktadır (Tablo-4). En sık tercih edilen ilk üç uzmanlık kadınlarda Çocuk Sağlığı ve Hastalıkları $(\% 13,6)$, Kadın Hastalıkları ve Doğum $(\% 10,3)$ ile Göz Hastalıkları $(\% 6,4)$ iken, erkeklerde Ruh Sağlığı ve Hastalıkları $(\% 7,6)$, Genel Cerrahi $(\% 6,7)$ ve Ortopedi ve Travmatoloji $(\% 6,1)$ olarak şekillenmektedir. Tıp eğitiminin ilk üç yılını kapsayan preklinik dönem öğrencilerinde en sık tercih edilen uzmanlık alanları \% 7,8 ile Kadın Hastalıkları ve Doğum, \%7,6 ile Çocuk Sağlığı ve Hastalıkları ve \%7,6 ile Ruh Sağlığı ve Hastalıkları, tıp eğitiminin 4. ve 5. yıllarını kapsayan klinik dönemde $\% 14,9$ ile Çocuk Sağlığı ve Hastalıkları, \%8,4 ile Göz Hastalıkları ve \%6,0 ile Kardiyoloji, intörnlük döneminde ise \%10,3 ile Çocuk Sağlığl ve Hastalıkları, \%8,0 ile Anesteziyoloji ve Reanimasyon ve \%5,7 ile Kadın Hastalıkları ve Doğum olarak ön plana çıkmaktadır.

Uzmanlaşmak isteyen öğrencilerin tercih ettikleri uzmanlı alanlarının belirlenmesinde etkili olduğunu ifade ettikleri en sık 5 neden \%46,0 ile uzmanlık alanındaki uygulamalara yeteneğinin olduğunu düşünmesi, \%45 ile uzmanlık alanındaki hastalara ilgi duymak, \%44,1 ile uzmanlık alanındaki hasta grubunun özellikleri, \%33,9 ile aile ve yakınlarındaki hastalara yardımcı olmak ve \%33,2 ile derslerin ve stajların etkisidir (Tablo-5). Öğrencilerin uzmanlık alanı tercihlerinde en az etkili olduğunu ifade ettikleri 5 neden ise \%6,6 ile istediği uzmanlık alanında uzmanlık almış bir yakınının olması, $\% 7,0$ ile tercih ettiği uzmanlık alanının mecburi hizmette daha rahat olması, \%8,1 ile ail eve yakın çevrenin yönlendirmesi, \%8,8 ile tercih ettiği uzmanlık alanında bakılan hasta sayısının az olması ve \%9,3 ile tercih ettiği uzmanlı alanındaki hastaların takip süresinin kısa olmasıdır. 
Tablo 4. Tıp öğrencilerinin en sık tercih ettiği on uzmanlık alanı $(n=798)$.

\begin{tabular}{lcc}
\hline Uzmanlık Alanı & $\mathrm{n}$ & $\%$ \\
\hline Çocuk Sağlı̆̆ı ve Hastalıkları & 79 & 9,9 \\
Kadın Hastalıkları ve Doğum & 53 & 6,6 \\
Ruh Sağlı̆̆ı ve Hastalıkları & 52 & 6,5 \\
Göz Hastalıkları & 44 & 5,5 \\
Kardiyoloji & 39 & 4,9 \\
Genel Cerrahi & 38 & 4,8 \\
İç Hastalıkları & 36 & 4,5 \\
Plas,Rek, ve Estetik Cerrahi & 32 & 4,0 \\
Kalp Damar Cerrahisi & 31 & 3,9 \\
Nöroloji & 30 & 3,8 \\
\hline
\end{tabular}

Uzmanlık alanı tercihinde en sık etkisi olan nedenler temel bilimler alanını seçen öğrencilerde \%71,4 ile uzmanlık alanındaki laboratuvar ve araștırma ortamını seviyor olmak, \%64,2 ile bu alanda hekime yönelik şiddetin az olması ve \%64,3 ile kendisine ve ailesine zaman ayırma isteği iken, dahili bilimler alanında uzmanlık eğitimi yapmak isteyenlerde \%52,9 ile uzmanlık alanındaki hastalara ilgi duymak, \%43,7 ile uzmanlık alanındaki uygulamalara yeteneği olduğunu düşünmek ve $\% 41,2$ ile tıp eğitiminde gördükleri derslerin/stajların etkisi, cerrahi bilimler alanında uzmanlık eğitimi yapmak isteyenlerde \%51,5 ile uzmanlık alanındaki uygulamalara yeteneği olduğunu düşünmek, $\% 42,0$ ile uzmanlık alanındaki hastalara ilgi duymak ve $\% 37,9$ ile maddi kaygı ve beklentilerdir. Benzer bir değerlendirme öğrenciler tarafindan en sik tercih edilen uzmanlık alanları özelinde yapıldığında, öğrencilerce $\% 9,9$ ile en çok tercih edilen Çocuk Sağlığı ve Hastalıkları alanında bu alandaki hastalara ilgi duymak, öğrencilerce
\%6,6 ile ikinci sıklıkta tercih edilen Kadın Hastalıkları ve Doğum alanında uzmanlık alanının kendi cinsiyetine uygun olduğunu düşünmek, öğrencilerce $\% 6,5$ ile üçüncü sıklıkta tercih edilen Ruh Sağlığı ve Hastalıkları alanında bu uzmanlık alanındaki hasta grubunun özellikleri en sik nedenler olarak belirtilmiştir.

\section{Tartışma}

Tıp öğrencilerinin uzmanlaşma eğilimi ve uzmanlık alanlarına yönelik tercihleri çok sayıda değişkenin birlikte etkisinin bulunduğu karmaşık bir etkileşim sürecinin sonucudur. Bununla birlikte tıp öğrencilerinin uzmanlaşma yönündeki yoğun istekliliği de uzun süreden beri bilinen bir olgudur. Çalışmamıza katılan 798 tıp öğrencisinin \%85,7'si mezun olduktan sonra uzmanlık eğitimine başlamak istediğini belirtmiştir. Uzmanlaşma isteği kadınlarda, tıp eğitiminin ilk 3 yılını kapsayan preklinik öğrencilerinde, aile ve akrabalarında hekim ya da uzman hekim bulunanlarda daha yüksektir. Uzmanlaşma isteği 1995-1996'da İstanbul Üniversitesi Cerrahpaşa Tıp Fakültesi Dönem 2-6 öğrencilerinde \%89,6,2 1993'de Ankara'da bir Tıp Fakültesi Dönem 1-6 öğrencilerinde \%92,8, ${ }^{3}$ 2004-2006'da Ondokuz Mayıs, Karadeniz Teknik, Kocaeli ve Adnan Menderes Üniversiteleri Tıp Fakülteleri Dönem-1 öğrencilerinde \%99,6,4 2011'de Pamukkale Üniversitesi Tıp Fakültesi Dönem 1, 3 ve 6 öğrencilerinde \%98,4,5 2016'da Akdeniz Üniversitesi Tıp Fakültesi Dönem 6 öğrencilerinde $\% 92,9$ olarak tespit edilirken, ${ }^{6}$ 2012-2013'de Düzce Üniversitesi Tıp Fakültesi Dönem 5 ve 6 öğrencilerinde yapılan çalışmada öğrencilerin tümü TUS'a girmek istediğini belirtmiştir. ${ }^{7}$ Hekim adaylarının uzmanlaşma tercihlerinin \%85,7100,0 arasında değiștiği söz konusu çalışmaların bir kısmı Sağlıkta Dönüşüm Programı ve Aile Hekimliği uygulamalarının başlangıcından önceye ait olmakla birlikte, söz konusu değişim öncesinde ve sonrasında hekim adaylarının uzmanlaşma eğilimlerinin sürekliliği dikkat çekicidir. 
Tablo 5. Tıp öğrencilerinin uzmanlık alanı tercihlerinde etkili olan nedenlera

\begin{tabular}{|c|c|c|}
\hline Nedenler: & $\mathrm{n}$ & $\%$ \\
\hline Uzmanlık alanındaki uygulamalara yeteneğinin olduğunu düşünmek & 315 & 46,0 \\
\hline Uzmanlık alanındaki hastalara ilgi duymak & 308 & 45,0 \\
\hline Uzmanlık alanındaki hasta grubunun özellikleri & 302 & 44,1 \\
\hline Ailedeki/yakındaki hastalara yardımcı olmak & 232 & 33,9 \\
\hline Derslerin/stajların etkisi & 227 & 33,2 \\
\hline Cinsiyete uygunluk & 209 & 30,5 \\
\hline Uzmanlık alanına toplumun gösterdiği saygı & 208 & 30,4 \\
\hline Maddi kaygı ve beklentiler & 200 & 29,2 \\
\hline İlgili alanın hocalarının tavır ve davranıșları & 198 & 28,9 \\
\hline Uzmanlık alanındaki tedavi sonuçlarının gözle görülür olması & 192 & 28,0 \\
\hline Kendine/aileye zaman ayırma isteği & 183 & 26,7 \\
\hline Uzmanlık alanındaki nöbet sayısının azlığı & 181 & 26,5 \\
\hline Uzmanlık alanının Türkiye'de diğer alanlara göre daha rahat icra edilebilmesi & 173 & 25,3 \\
\hline Uzmanlık alanında özelde çalışabilme ve muayenehane açabilme olanağı & 171 & 25,0 \\
\hline O alanda örnek aldığı bir kişinin olması & 171 & 25,0 \\
\hline Uzmanlık alanındaki malpraktis riskinin azlığı & 158 & 23,0 \\
\hline Uzmanlık alanının yurt dıșında çalıșma olanağının daha fazla olması & 154 & 22,5 \\
\hline Uzmanlık alanındaki hekime şiddet riskinin azlığı & 154 & 22,5 \\
\hline Uzmanlık alanındaki laboratuvar ve araştırma ortamını seviyor olmak & 149 & 21,8 \\
\hline Hayati tehlikesi olan hastalarla ilgilenmek istememek & 136 & 19,9 \\
\hline Uzmanlık alanındaki yükselme olanağının fazla olması & 123 & 18,0 \\
\hline Uzmanlık alanın acilinin olmaması & 115 & 16,8 \\
\hline Uzmanlık alanının TUS puanının düşük olması & 107 & 15,6 \\
\hline Uzmanlık alanındaki hiyerarşinin diğer bölümlere göre daha az olması & 95 & 13,9 \\
\hline Uzmanlık alanının asistan eğitiminin süresi & 81 & 11,8 \\
\hline Uzmanlık alanının partneri ile olan ilişkisi için daha uygun olması & 75 & 11,0 \\
\hline Uzmanlık alanının hasta ile iletişiminin olmaması & 68 & 10,0 \\
\hline Uzmanlık alanındaki hastaların takip süresinin kısa olması & 64 & 9,3 \\
\hline Uzmanlık alanında bakılan hasta sayısının daha az olması & 60 & 8,8 \\
\hline Aile ve yakın çevrenin yönlendirmesi & 56 & 8,1 \\
\hline Uzmanlık alanının mecburi hizmette daha rahat olması & 48 & 7,0 \\
\hline İstediğim uzmanlık alanında uzmanlık almıș bir yakınımın bulunması & 45 & 6,6 \\
\hline
\end{tabular}

aKatılımcılar birden fazla seçeneği işaretleyebilmekteydi 
Tıp öğrencileri ve hekimlerin uzmanlaşma eğilimi farklı ülkelerde yapılan çalışmalarda da tespit edilen bir olgudur. Ülkemizde mevcut kullanımı ile "pratisyen hekim" tıp fakültesini bitirmiş olan hekimleri tanımlamakta, pratisyen hekimler arasında Aile Sağlığı Merkezlerinde görev alan hekimler bir uzmanlık alanı ile de örtüșecek biçimde "aile hekimi" olarak adlandırılırken, idari görevler üstlenen ya da acil servisler, 112 ekipleri veya Toplum Sağllğ Merkezlerinde görev alan hekimler ise "pratisyen hekim" olarak adlandırılmaktadır. Bununla birlikte, farklı ülkelerde tıp eğitiminin farklılıklar içermesi, genel pratisyenliğin bir uzmanlık alanı olarak belirlenip belirlenmemesi gibi nedenlerle ülkeler arasında karşılaştırma yapmak zorluklar içermektedir. Örneğin, 2010 yılında Almanya'da gerçekleştirilen bir çalışmada katılımcıların \%85,8'i uzmanlaşmak istediğini belirtirken bunların \%7,0'llk kısmı uzmanlaşmak istedikleri alanı genel pratisyenlik olarak ifade etmişlerdir. ${ }^{8}$ Birleşik Krallık'ta 2016'da yapılan çalışmada uzun vadeli kariyer planlarına yönelik ilk seçimlerini hekimlerin \%67,3'ü uzmanlaşmak, $\% 28,8$ 'i genel pratisyenlik olarak belirtirken, ${ }^{9}$ tıp öğrencilerinin, Fransa'da 2008'de gerçekleștirilen çalışmada \%87,0' uzmanlaşmak istediğini, ${ }^{10}$ İrlanda'da 2015 'de yapılan çalışmada \%18,0'ı kariyer seçimini genel pratisyenlik yönünde yaptığını belirtmiştir. ${ }^{11}$

Hekimlerin ve hekim adaylarının ikinci ve üçüncü basamak sağlık hizmetlerinde çalışacakları uzmanlık alanlarına yönelmeleri birinci basamak sağlık hizmetlerinin sürekliliği ve sürdürülebilirliği üzerinde olumsuz bir etki yaratabilir. Örneğin, Gouda ve arkadaşları ${ }^{11}$, İrlanda'da genel pratisyen ücretlerinin Avrupa'nın en düşügü olduğunu, genel pratisyenlerin \%13,2'sinin 65 yaş ve üzerinde olduğunu, genel pratisyenlerin 1/3'ünün yabancı hekimler olduğunu ve bu konuda OECD ülkeleri içerisinde ilk sırada yer alan İrlanda'da 2021 yılına yönelik planlamalarda \%5,7 eksiklik olduğunu, ekonomik kriz dönemlerinde tıp öğrencilerinin tercihlerinin uzmanlaşmak yönünde eğilim gösterdiğini belirtirken, Kiolbassa ve arkadaşlari ${ }^{8}$ Almanya'da doktorların sadece \%7,0'inın genel pratisyenlik yönünde tercihleri olduğunu, uzmanlaşma oranının giderek arttığını, pratisyen hekimlerin yarısının 65 yaş ve üzerinde olduğunu vurgulamaktadır. Genel pratisyen iş gücünün azaldığl, sorunun özellikle kırsal alanda daha belirgin olduğu, genç hekimlerin genel pratisyenliği tercih etmediği gibi, çocuklarının bakımı ve eğitimi, boş zaman etkinliklerine yönelik olanakların kısıtlılı̆̆ı gibi nedenlerle kırsal bölgelerde çalışmayı tercih etmedikleri çeşitli araştırmacılar tarafından da vurgulanmaktadır.8,12,13

Tıp öğrencilerinin henüz eğitim aşamasındayken yüksek oranda uzmanlaşma eğiliminde olması, hekim adaylarının pratisyen hekim ve uzman hekim arasında belirgin bir ayrıştırmaya sahip olduğunu göstermektedir. Bu isteğin șekillenmesine etki eden etmenlerin değerlendirilmesi sağlık insan gücü politika ve planlamalarının gerçekçiliği yönünden önemli bir role sahiptir. Bununla birlikte, hekim adaylarının henüz eğitim aşamasında sahip oldukları uzmanlaşma isteği kapsamında, uzmanlık alanı seçimine yönelik tercihleri de eğitim sırasında değişiklikler geçirmektedir. Çalışmamızda öğrencilerin \%46,5'inde tıp eğitimi sırasında uzmanlık tercihlerinde değişiklik olduğu saptanmıştır. Tıp öğrencilerinin kariyer planlarının öğrencilik aşamasında, hatta kimi zaman tıp eğitimine başlamadan ş̧ekillendiği, kariyer planlamalarının tıp eğitimi esnasında değişikliklere uğradığı farklı araştırmalarda da belirtilen bir olgudur.6.8.14

Hekim adaylarının ve/veya hekimlerin
mesleki kariyer planlamalarında
yanıtlamaları gereken ilk soru uzmanlaşmayı
isteyip istemedikleri yönündedir ve
araştırmaların da gösterdiği gibi bu sorunun
yanıtı büyük bir yoğunlukla uzmanlaşma
yönündedir. Çalışmamızda tıp öğrencilerini
uzmanlaşmaya yönelten en önemli etkenler
mesleki tatmin sağlayacak özel bir alanda


çalışma isteği, statü ve kariyer beklentisi, maddi kayglar ve pratisyen hekimliğin değersiz olarak algılanmasıdır. Bunların yanı sıra uzmanlık eğitiminin bir başarı göstergesi olarak alglanması, pratisyen hekimliğe yönelik ulusal sağlık politikaları, aile/toplum baskısı ve özel sektörde çalışma isteği de öğrenciler tarafından gerekçeler arasında belirtilmiştir. Ülkemizde tıp öğrencilerini uzmanlaşmaya yönlendiren nedenleri irdeleyen çalışmalarda öne çıkan nedenler Dörtyol'un ${ }^{6}$ çalışmasında mesleki tatmin ve kariyer yapma olanağl, Ergin ve arkadaşlarının ${ }^{5}$ çalışmasında mesleki tatmin, daha iyi gelire sahip olmak, akademik kariyer olanağı ve daha yüksek sosyal statü/prestij, Kara ve arkadaşlarının ${ }^{7}$ çalışmasında aile ve özel yaşam, akademik kariyer olanağı, Dikici ve arkadaşlarının ${ }^{4}$ çalışmasında ise maddi gelir ve prestij, kişisel gelişim olarak belirlenmiştir.

Farklı ülkelerde yapılan çalışmalar, farklılıklar içermekle birlikte, ana hatta benzer gerekçelerin ön plana çıtığını desteklemektedir. ABD'de yaşam biçimi tercihleri ve yüksek gelir beklentisi uzmanlaşmaya yönelmede öne çıkan nedenler olarak saptanırken,15,16 Almanya'da gelecek beklentisi, iş-hayat dengesi ve kişisel isteklerden oluşan kişisel etkenlerin mesleksel etkenlerden daha ön planda olduğu ve gelecek beklentisinin belirgin rol oynadığı ${ }^{8}$ Macaristan'da yüksek gelir ve statü beklentisinin, ${ }^{17}$ Saudi Arabistan'da yaşam beklentisinin ön planda olduğu vurgulanmıştır. ${ }^{18}$ Hekimlerin hastanede çalışmak istemesi de uzmanlaşmayı destekleyen nedenler arasındadır.15,19 Querdio ve $\operatorname{arkadaşları~}^{20}$ ise, uzmanlık seçimindeki belirleyici faktörleri tıp fakültesinde alınan eğitimin içeriği, öğrencilerin karakteristik/kişisel özellikleri, öğrencilerin kişisel değer yargıları/tercihleri, uzmanlık alanının algılanışı ve gelir, statü veya iş-hayat dengesi gibi tatmin olmak istedikleri özellikler olarak 5 gruba ayırmaktadır.

Tıp öğrencilerinin ve hekimlerin uzmanlaşmaya yönelmesinde uzmanlığa ilişkin görüş ve algılarının yanında, genel pratisyenliğe yönelik düşünce ve algılar da belirleyici role sahiptir. $\mathrm{Bu}$ kapsamda, pratisyen hekimlikte gelirin daha düşük olması, ${ }^{21-23}$ iş yükü yoğunluğu, ${ }^{22}$ meslektaşları tarafından yeterli saygl görmemek, ${ }^{21}$ toplumsal statünün/prestijin düşük olması, ${ }^{21}$ gerekli tıp bilgisinin daha geniş olması, ${ }^{21}$ kağıt işleri, formlar ve telefon konuşmaları gibi yönetsel işlerin yoğunluğu, ${ }^{22}$ pratisyen hekimliğin kişisel beklentileri karşılayamaması ${ }^{6,8}$ öne çıkan görüşler olarak izlenmektedir. Toplumun yaşlanması ile birlikte geriatrik hastaların artması ve birinci basamağa başvuran hastaların daha karmaşık klinik tablolarla gelmesinin ögrencileri ve hekimleri genel pratisyenlikten uzaklaştırdığ da değinilen konular arasındadır. ${ }^{8}$ Dikkat çeken bir diğer etken de temel sağlık hizmetlerinin ve birinci basamak sağlık hizmetlerinin ülkedeki konumudur. ${ }^{24}$ Örneğin, Huda ve Yousuf ${ }^{21}$ Pakistan'da sağlık hizmet sunucularındaki yetersizlik, hasta sayısındaki artış ve finansal darlıklar nedeniyle temel sağlık hizmetlerinde gerileme yaşandığını, bu durumun öğrencileri mesleki kariyer planlarından birinci basamak sağlık hizmetlerinde çalışmaktan uzaklaştırdığını, üniversitelerin toplum temelli aktivitelere ağırlık vermesine karşın öğrencilerin bu alanı seçmediğini, sağlık sistemi ve tıp eğitiminin ülkenin genel pratisyen hekim gereksinimini karşılamakta yetersiz kaldığını vurgulamaktadır. $\mathrm{Bu}$ anlamda ilgi çekici vurgulamalardan biri de Kiolbassa ve arkadaşlarına $^{8}$ aitdir; araştırmacılar, Sosyal Güvenlik Sağlı Sistemi'ne sahip olan Almanya'da sistemin Birleşik Krallık, İspanya ve İsveç gibi Ulusal Sağlık Hizmetleri'ne (NHS) sahip olan ülkelerden daha bağımsız olduğu, sistemin sağlık hizmeti sunucuları ile çoğulcu ve güçlü bir iletişime sahip olduğu, genel pratisyenlik için yapılandırılmış bir eğitim bulunmadığı, mesleki eğitimin diğer Batı Avrupa ülkelerine oranla daha düşük bir imaja sahip olduğu ve hekimlerin uzmanlık eğitimine kolaylıkla ulaşabilirliği, genel pratisyenlerin bireylerin uzmanlık gerektiren sağlık hizmetlerine ulaşımında kapı tutucu bir role sahip olmadıkları ve bireylerin bu 
hizmetlere ulaşımının kolaylığına değinirken, NHS'de çalışan genel pratisyenlerin bireylerin uzmanlık alanı gerektiren sağlık hizmetlerine ulaşımında karar verici ve belirleyici rol oynadıklarına, genel pratisyenlik tercihinin Birleşik Krallık'ta Almanya'dan daha yüksek olduğuna değinerek, hekim adaylarının ve hekimlerin genel pratisyenliği tercih etmesinde genel pratisyenlerin çalışma koşullarının önemine vurgu yapmaktadır. Newton ve arkadaşları ${ }^{15}$ ABD'de tıp öğrencilerinin birinci basamakta uzmanlaşmayı da diğer uzmanlık alanları gibi bir yaşam biçimi olarak algıladıklarına, bazı uzmanlık alanlarını yaşam biçimini zorlaştırıcı, bazılarını ise kolaylaştırıcı olarak değerlendirirken, birinci basamak için bu etkinin orta derecede olduğunu düşündüklerine dikkat çekmektedir.

Hekim adaylarin ve hekimlerin mesleki kariyer planlarında uzmanlaşma kararını verdikten sonra yanıtlamaları gereken ikinci soru hangi uzmanlık alanının seçileceğidir ve bu kararda da kişisel ve mesleki beklentiler gibi çok sayıda değişkenin etkileşimi söz konusudur. Tıp eğitimi alınan fakültenin sosyal çevresi, eğitim programı, öğrencilerin eğitim esnasında karşılaştıkları rol modeller, uzmanlık alanına atfedilen sosyal statü, uzmanlık alanına özgü hastaların özellikleri, aile ve yakın çevrenin önerileri, alanda çalışan uzman sayısı ve uzmanlık eğitiminin içeriği de bu kararda rol oynayabilir. ${ }^{15,21}$ Çalışmamızda öğrenciler tarafından en sık tercih edilen uzmanlık alanları Çocuk Sağlığı ve Hastalıkları, Kadın Hastalıkları ve Doğum, Ruh Sağlığı ve Hastalıkları olarak saptanmıștır. Ülkemizde yapılan çalışmalarda ön plana çıkan uzmanlık alanı tercihleri Kara ve arkadaşlarınca ${ }^{25}$ Dermatoloji, Kardiyoloji ve Radyoloji, Tekin ve arkadaşlarınca $^{26}$ Göz Hastalıkları, Kardiyoloji, Kadın Hastalıkları ve Doğum ve Ruh Sağlığı ve Hastalıkları, Ergin ve arkadaşlarınca $^{5}$ Kardiyoloji ve Göz Hastalıkları, Kara ve arkadaşlarınca ${ }^{7}$ KBB, Dermatoloji, Dahiliye, Plastik Cerrahi ve Ruh Sağlığı ve Hastalıkları, Dikici ve

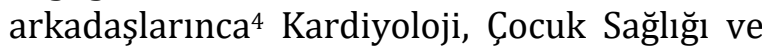

Hastalıkları, Göz Hastalıkları, FTR ve Kadın Hastalıkları ve Doğum olarak saptamıştır. Diğer ülkelerde yapılan çalışmalarda Hollanda'da Dahiliye, Psikiyatri ve Radyoloji, ${ }^{27}$ Pakistan'da Dahiliye, Genel Cerrahi ve Pediatri, ${ }^{21}$ Almanya'da Dahiliye, Kadın Doğum, Pediatri, Genel Cerrahi ve Anestezi, ${ }^{8}$ Fransa'da Pediatri ve Kadın Doğum ${ }^{10}$ öne çıkan uzmanlık alanları olarak belirtilmiştir. Lambert ve arkadaşları ${ }^{9}$ Birleşik Krallık'ta Anestezi, Psikiyatri ve Radyolojiye eğilimin arttığını belirtmektedir.

Hekim adaylarının ve hekimlerin uzmanlı alanı tercihlerinin etkileyen etmenlerde farklı çalışmalarda belirgin örtüşmeler izlenmektedir. Çalışmamızda hekim adaylarının uzmanlı alanı tercihlerinde en sık etkisi olan etmenler uzmanlık alanına yönelik yeteneği olduğunu düşünmek, uzmanlık alanına özgü hasta grubu, ailedeki/yakın çevredeki hastalara yardımcı olmak, derslerin/stajların etkisi, cinsiyete uygunluk ve uzmanlık alanına gösterilen toplumsal saygı olarak belirginleşmektedir. Ülkemizde yapılan çalışmalarda öne çıkan nedenler yüksek gelir beklentisi, kişisel algının yanı sıra, nöbet varlığı, çalışma saati yoğunluğu ve malpraktis riski gibi uzmanlık alanına özgü çalışma koşullarıdır.2,6 Diğer ülkelerde yapılan çalışmalarda da benzer gerekçeler dikkat çekmektedir; kontrol edilebilir bir yaşam biçimine ulaşmak, ${ }^{15,16}$ iş ve özel hayat arasında uygun bir denge yakalamak, ${ }^{8}$ yüksek maddi gelir beklentisi, ${ }^{8,15,21,28}$ kişisel ilgi ${ }^{21}$ önde gelen gerekçelerdir.

Uzmanlık alanı tercihlerinde dikkat çeken bir olgu da cinsiyete göre farklılaşmadır. Benzer yönelim çalışmamızda da tespit edilmiştir. Kadınların dahili bilimler, erkeklerin cerrahi bilimlerde yer alan uzmanlık alanlarına yöneldikleri, kadınların cerrahi bilimler alanındaki kadın doğumu da sıklıkla tercih ettikleri, kadınların aile yaşamı ile daha uyumlu çalışma koşullarına yöneldikleri, hastaları ile yakın temasta olmayı tercih ettikleri, buna karşılık erkeklerin prestij ve araştırma koşullarından 
daha çok etkilendikleri farklı araştırmacılar tarafindan da vurgulanmaktadır.5,8,12,29

Gerek hekim adayları gerekse de hekimler arasında yoğun biçimde izlenen uzmanlaşma eğilimi ve belirleyici etkenler birlikte değerlendirildiğinde, uzmanlaşma eğiliminin ve uzmanlık alanlarına yönelik tercihlerin henüz tıp eğitimi aşamasındayken, hatta kimi zaman eğitim öncesinde şekillendiği gözlenmektedir. Bu durum, tıp eğitiminin "nitelikli pratisyen hekimler yetiştirmek" șeklinde özetlenebilecek genel amacı ile belirgin bir çelișki içerirken, temel sağlık hizmetlerinin güçlendirilmesine yönelik sağlık insangücü politika ve planlamalarını da olumsuz etkilemektedir. Hekim adaylarını ve hekimleri uzmanlaşmaya yönlendiren gerekçelerin ve beklentilerin tespit edilerek tartışılması, süreklilik içerecek biçimde incelenerek değerlendirilmesi, özellikle pratisyen hekimlerin çalışma koşullarının iyileştirilmesi ve pratisyen hekimliğe yönelik olarak hekim adayları, hekimler ve toplum tarafından atfedilen değerin yükseltilmesi, sağlık hizmetlerinin ve buna bağlı olarak toplum sağlığının geliștirilmesine yönelik çabaların başarıya ulaşabilmesi için önemli ve öncelikli bir başlangıç noktası oluşturmalıdır.

Yazarların katkısı: Araştırmacıların tümü çalışmanın planlanması, veri toplanması ve analiz, çalışma metninin yazılması aşamalarına aktif olarak katılmıştır.

\section{Kaynaklar}

1. Sağlik Bakanlığı. Sağlık İstatistikleri Yıllığı 2017 Haber Bülteni. Erişim yeri: www.saglik.gov.tr. Erişim Tarihi: 01.12.2018.

2. Köksal S, Vehid S, Tunçkale A, Çerçel A, Erginöz E, Kaypmaz A, Sipahioğlu F, Özbal AN. Cerrahpaşa Tıp Fakültesi öğrencilerinin tıp eğitimi ve mezuniyet sonrası ile ilgili tutumları. Cerrahpaşa Tıp Dergisi 1999;30(4):251-258.
3. Bakır B. Bir tıp fakültesi öğrencilerinin mezuniyet sonrası beklentileri. Toplum ve Hekim 1994;9(60):63-67.

4. Dikici MF, Yaris F, Topsever P, Filiz TM, Gurel FS, Cubukcu M, Gorpelioglu S. Factors affecting choice of speciality among first-year medical students of four universities in different regions of Turkey. Croatian Medical Journal 2008;49:415420.

5. Ergin A, Dikbaş E, Bozkurt Aİ, Atçeken G, Gürbüz H, Yılmaz C, Çölbe SN, Tașçı U, Güldamla L, Demircan Hİ. Tıp fakültesi öğrencilerinin mezuniyet sonrası kariyer seçimi ve etkileyen faktörler. Tıp Eğitimi Dünyası 2011;32(32):8-17.

6. Dörtyol BG. Tip fakültesi son sinıf öğrencilerinin mezuniyet sonrası ile ilgili düşünceleri, kariyer seçimleri ve etkileyen faktörler. Tıp Eğitimi Dünyası 2017;16(50):12-21.

7. Kara İH, Çelik S, Keyif MF, Demir A, Baltacı D, Mayda AS. Düzce Üniversitesi Tıp Fakültesi 5. ve 6. sınıf öğrencilerinin brans tercihleri ve Tipta Uzmanlık Sinavı'na bakışlarının incelenmesi. Konuralp Tıp Dergisi 2014;6(2):11-18.

8. Kiolbassa K, Miksch A, Hermann K, Loh A, Szecsenyi J, Joos S, Goetz K. Becoming a general practitioner-Which factors have most impact on career choice of medical students? BMC Family Practice 2011;12:25-31.

9. Lambert TW, Smith F, Goldacre MJ. Career speciality choice of UK medical graduates of 2015 compared with earlier cohorts: questionnaire surveys. BMJ 2018;94:191197.

10. Lefevre JH, Roupret M, Kerneis S, Karila L. Career choices of medical students: a national survey of 1780 students. Medical Education 2010;44:603-612.

11. Gouda P, Fanous S, Sloane PA, Murphy AW. Medical student and general practitioner perceptions of challenges in general practice in Ireland. Irish Medical Journal 2016;109(5):414.

12. Jaafar R, Ahmed Z. Career preferences of medical students in a community-oriented medical school. Annals of Network of 
Community Oriented Education 1993;6:301-310.

13. Dambisya Y. Career intentions of UNITRA medical students and their perceptions about the future. Education for Health 2003;16:286-297.

14. Petrides KV, McManus IC. Mapping medical careers: questionnaire assessment of career preferences in medical school applicants and final-year students. BMC Medical Education 2004;4:4-18.

15. Newton DA, Grayson MS, Thompson LF. The variable influence of lifestyle and income on medical students' career specialty choices: Data from two U.S. medical schools, 1998-2004. Academic Medicine 2005;80(9):809-814.

16. Dorsey ER, Jarjoura D, Rutecki GW. The influence of controllable lifestyle and sex on the specialty choices of graduating U.S. medical students, 1996-2003. Academic Medicine 2005;80(9):791-796.

17. Girasec E, Molnar R, Eke E, Szocska M. The medical career choice motivations results from a Hungarian study. Central Eurpean Jornal of Medicine 2011;6(4):502-509.

18. Alshahrani M, Dhafery B, Al Muhlim M, Alkhadra F, Al Bagshi D, Bukhamsin N. Factors influencing Saudi medical students and interns' choice of future speciality: A self-administered questionnaire. Advances in Medical Education and Practice 2014;5:397-402.

19. Campos D, Senf J, Kutob R. Comments heard by U.S. medical students about family practice. Family Medicine 2003;35:573-578.

20. Querido SJ, Vergouw D, Wigersma L, Batenburg RS, De Rond MEJ, Ten Cate OTJ. Dynamics of career choice among students in undergraduate medical courses. A BEME systematic review: BEME Guide No 33. Medical Teacher 2016;38(1):18-29.

21. Huda N, Yousuf S. Career preference of final year medical students of Ziauddin Medical University. Education for Health 2006;19(3):345-353.
22. Manca D, Varnhagen $S$, Brett-MacLean $P$, Allan G, Szafran O, Ausford A, Rowntree C, Rumzan I, Turner D. Rewards and challenges of family practice: Web-based survey using the Delphi Method. Canadian Family Physician 2007;53:277-286.

23. Scott I, Wright B, Brenneis F, BrettMacLean P, McCaffrey L. Why would I choose a career in family medicine?: Reflections of medical students at 3 universities. Canadian Family Physician 2007;53:1956-1957.

24. Starfield B. A new paradigms for quality in primary care. British Journal of General Practice 2001;51:303-309.

25. Kara İH, Üzüm HG, Deler MH, Yılmaz A, Baltacı D, Gürel FS. Düzce Üniversitesi Tıp Fakültesi internlerinin branş tercihleri ve TUS kazanma durumlarının incelenmesi. Eurasian Journal of Family Medicine 2013;2(1):11-18.

26. Tekin Ç, Güneş G, Türkol E. İnönü Üniversitesi Tıp Fakültesi öğrencilerinin tıpta uzmanlık tercihleri ve etkileyen faktörler. İnönü Üniversitesi Sağllk Bilimleri Dergisi 2013;1:5-10.

27. van Dee V, van der Klis BM, van Dijk MR. Career development of medical school graduates: comparison of medical students from Utrecht, Lieden and Groningen. Nederland Tijdschrift voor Geneeskunde 2017;160(0):D504. (abstract in English)

28. Baboolal NS, Huchhinson GA. Factors affecting future choice of specialty among first-year medical students of the University of the West Indies, Trinidad. Medical Education 2007;41:50-56.

29. Reed V. Fischer BB. Career obstacles for women in medicine: An overview. Medical Education 2001;35:139-147. 